\title{
Die stemaanvangstyd van apraktiese en disartriese sprekers
}

\author{
Erentia Gillmer B (Log) (Pret); Anita van der Merwe MA (Log) (Pret)† \\ "Addington Hospitaal Durban en tDepartement \\ Spraakwetenskap, Spraakheelkunde en Oudiologie \\ Universiteit van Pretoria
}

\begin{abstract}
OPSOMMING
Die aard van die neuromotoriese disfunksie wat in verbale apraksie en verworwe disartrie voorkom word tans in diepte ontleed. 'n Belangrike vraag wat beantwoord moet word, is wat die verskil tussen hierdie twee tipes spraakprobleme is. In hierdie studie word die fonetiese parameter, stemaanvangstyd (SAT) ondersoek. Die doel is om te bepaal of kenmerkende afwykings in die SAT by verbale apraksie en verworwe disartrie voorkom. By. laasgenoemde is ataktiese en hipokinetiese disartrie ingesluit. Afwykende stemaanvangstye is by die ataktiese en apraktiese groepe gevind. Die meeste variasie in die gemete tydsintervalle is by die groep met ataktiese disartrie opgemerk. Stemhebbende klanke is deur beide groepe met stemlose klanke vervang. Onderbrekings in die stempulserings is by die apraktiese sprekers waangeneem. Daar is gevind dat daar verskille in SAT by die apraktiese en disartriese sprekers voorkom. Die verskille was egter klein en onkonstant.
\end{abstract}

\section{ABSTRACT}

The nature of the neuromotor dysfunction in verbal apraxia and acquired dysarthria is currently being analysed in great detail. An important question to be answered relates to the difference between these two types of speech disorders. In this study the phonetic parameter, voice onset time (VOT) was investigated. The aim was to determine whether characteristic deviations occur in verbal apraxia and acquired dysarthria. Within the latter, ataxic and hypokinetic dysarthria were considered separately. DeSubstitution of voiced the apraxic and ataxic groups. The greatest variation in time intervals was observed in ataxic dysarthria. in the apraxic speakers. the differences were small and inconsistent.

Neuromotoriese spraakprobleme ontvang tans baie aandag in die literatuur. 'n Voorbeeld van so 'n neuromotoriese spraakprobleem is verbale apraksie. Verbale apraksie word gedefinieer as artikulasiefoute wat die gevolg is van 'n defek, te wyte aan breinskade, in die programmering van eerstens die posisionering van spraakspiere vir die willekeurige produksie van foneme, en tweedens die opeenvolging van spierbewegings vir woordproduksie. ${ }^{6}$

Daar bestaan egter 'n polemiek oor die term apraksie. Sommige outeurs beskou verbale apraksie as 'n fonologiese eerder as 'n motoriese probleem. In die jongste literatuur is daar egter bewyse dat apraksie wél 'n uitval in spraakmotoriek is. Die studie deur Itoh, Sasanuma en Ushijima, ${ }^{6}$ wat die velêre bewegings tydens spraakproduksie by apraktiese sprekers ondersoek het, dien as so 'n bewys. Bogenoemde outeurs het 'n dissinchronisering tussen die velum en tong gevind, nl. die velêre jaling vir $/ n /$ het nie gekorreleer met dié van die tongbeweging vir apikale sluiting nie. 'n Fonetiese fout waar $/ \mathrm{n} / \mathrm{na} / \mathrm{d} / \mathrm{veran}$ ter, was die gevolg.
Die gemelde bevindings dui daarop dat die fonetiese vervangings van apraktiese sprekers nie die gevolg van 'n fonologiese uitval is nie, maar wel 'n uitval in spraakmotoriek.

Aan die ander kant is dit 'n welbekende fe'it dat disartrie 'n spraakmotoriese uitval is. Die vraag ontstaan nou wat presies die verskil tussen hierdie gemelde motoriese spraakprobleme is. Daar moet egter in gedagte gehou word dat disartrie nie 'n homogene afwyking is nie, maar eerder 'n versamelnaam vir 'n groep spraakafwykings wat deur 'n versteuring in die neuromuskulêre kontrole van die spraakmeganisme gekenmerk word. Hierdie muskulêre versteuring is die gevolg van letsels in die sentrale of perifere senuweesisteem. 'n Letsel in die basale ganglia het 'n hipokinetiese disartrie tot gevolg, terwyl 'n serebellêre letsel aanleiding gee tot 'n ataktiese disartrie. Die simptome van hierdie twee tipes disartrie stem nie ooreen nie. ${ }^{3}$ Om hierdie rede is beide die groepe disartrieë met verbale apraksie vergelyk.

Die fonetiese parameter stemaanvangstyd (SAT), word in hierdie studie ondersoek, aangesien die apraktiese en disartriese 
foute eers van mekaar onderskei kan word as die fonetiese aspekte van die foute begryp word.

Die doel van die studie is om te bepaal of daar enige beduidende afwykings in die SAT van apraktiese en disartriese sprekers is, en indien wel, wat die aard daarvan is; asook om te bepaal wat die verskil is, indien enige, tussen die SAT van apraktiese en disartriese sprekers.

\section{EKSPERIMENTELE METODE}

\section{PROEFPERSONE}

Die proefpersone in die eksperimentele groep het 'n verworwe neuromotoriese disfunksie vertoon en is deur twee groepe verteenwoordig, nl. 'n groep wat disartriese spraak vertoon (een proefpersoon met basale gangliaskade, $E_{1}$, en drie met serebellêre skade, $E_{2}, E_{3}$ en $E_{4}$ ) en 'n groep met apraktiese spraak $\left(E_{5}\right.$ en $\left.E_{6}\right)$.

Die proefpersoon met basale gangliaskade het Parkinsonisme gehad aangesien dit die enigste siektetoestand is wat in sy aanvangstadium 'n suiwer basale ganglialetsel verteenwoordig. Die apraktiese proefpersone is by die Spraakkliniek van die Universiteit van Pretoria gediagnoseer en die disartriese proefpersone is deur 'n neuroloog gediagnoseer. 'n Kontrolegroep $\left(\mathrm{K}_{1}-\mathrm{K}_{6}\right)$ wat met die eksperimentele groep ooreengestem het ten opsigte van geslag, ouderdom en taal, maar met die afwesigheid van 'n neuromotoriese disfunksie, is ingesluit.

\section{MATERIAAL}

Die materiaal het uit 20 eenlettergrepige sinvolle woorde met inisiële eksplosiewe konsonante $/ \mathrm{p} ; \mathrm{b} ; \mathrm{t} ; \mathrm{d} /$ bestaan. Die inisiële konsonante is deur die vokale en diftong /a; 0 ; $\mathrm{i}$; eeu; aa/onderskeidelik opgevolg.

'n Inleidende frase is ingesluit ten einde 'n meer natuurlike spraaksituasie te skep en om proefpersone (bv. apraktiese sprekers) wat sukkel om spraak te inisieer, van ander woorde as die "toetswoord" te voorsien.

Hierdie kort sinne is drie maal direk na mekaar deur die proefpersoon herhaal, sodat 'n gemidddelde telling verkry kon
word.

\section{VERWERKING VAN RESULTATE}

"Vpraakseinopnames is met behulp van 'n nr. 550 Nakamichi "Versatile Stereo Casette System" bandopnemer gemaak. Tyvandaar is die die data is hierdie opnames teruggespeel en gevoer. Hierdie digitale die Digitale Herhalingslyn Model 2A se spraak vir analitale herhalingslyn stoor ongeveer 2,5 sek. sein is op die skerm yan 'n 1200B) vertoon sodat van 'n ossilloskoop (Hewlett-Packard luidspreker is gebruik metings gemaak kon word. 'n Monitordie spraak kon luister. By klanke waar da

die begin van die ekspleen stem voor die eksplosief is nie, is loskoopskerm gestel van die skerm tot ware Die tydsmeting is vanaf die linkerkant doen. By klanke waar stem die stende klanke begin het, gebegin van die ossillasies die eksplosief voorafgaan, is die van die skerm gestel, en wat stem aandui aan die linkerkant plosief begin. In sulke gevalling is gedoen tot waar die eksDie Suid-Afrikaanse tytukif gevalle is die SAT negatief genoteer.
Daar word deurgaans in die studie melding gemaak van positiewe en negatiewe SAT-waardes. Ten einde enige verwarring uit te skakel, volg 'n kort verduideliking. Die skielike ontsnapping van lug met aanvang van die eksplosief word as " $O$ " geeksplosief vatiewe waardes dui die tyd aan waarmee stem die eksplosief voorafgegaan het (stemvoorloop).

$$
\underset{\begin{array}{c}
\text { Ontsnapping van lug } \\
\text { met aanvang van } \\
\text { die eksplosief }
\end{array}}{\stackrel{\mathrm{O}}{\mathrm{O}} \text { positiewe waardes }}
$$

Metings het getoon dat stemhebbende eksplosiewe van klanke onderskei word deur die aanvang van laringale vibrasies wat die "plof" òf voorafgaan of 'n kort stemnalooptyd toon. Hierloenoor word stemlose eksplosiewe deur 'n relatief langer nasieer met die stemer. Stemhebbende klanke word dus geassoval. Dit is 'n algemene verskynse in twee onderbroke gebiede vorsers gevind is. ${ }^{1,}, 13$

\section{RESULTATE}

Die resultate van metings word grafies in figure 1 tot 6 voorgestel. Die vier tipes aanvangsklanke word apart aangegee en vir

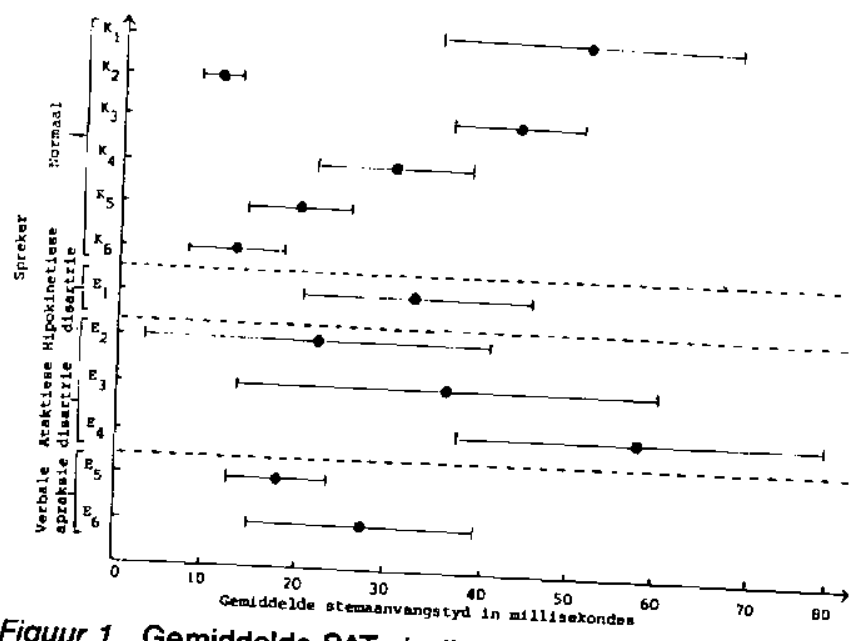

Figuur 1 Gemiddelde SAT vir die klank /p/ vir alle sprekers

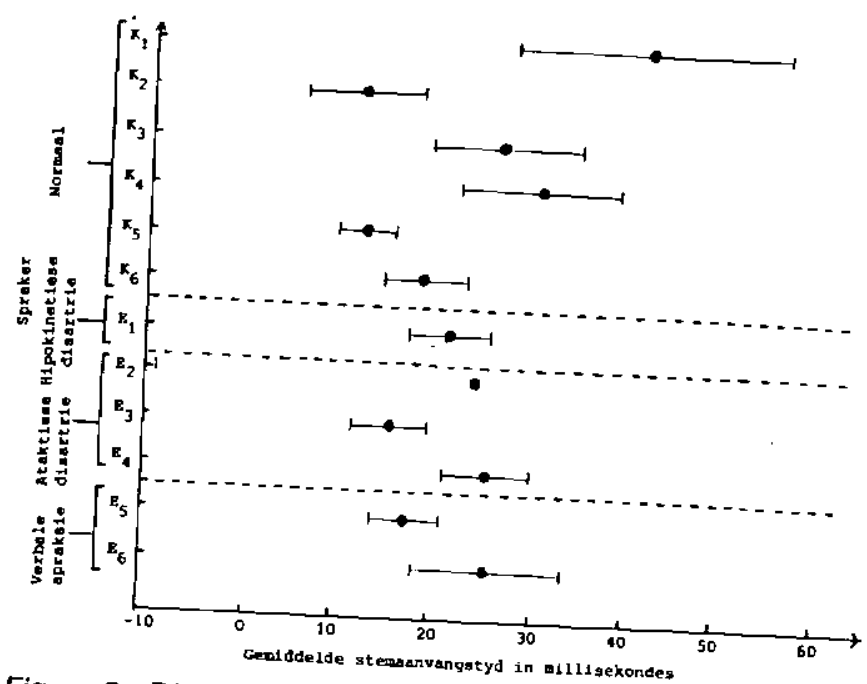

Figuur 2 sprekers 


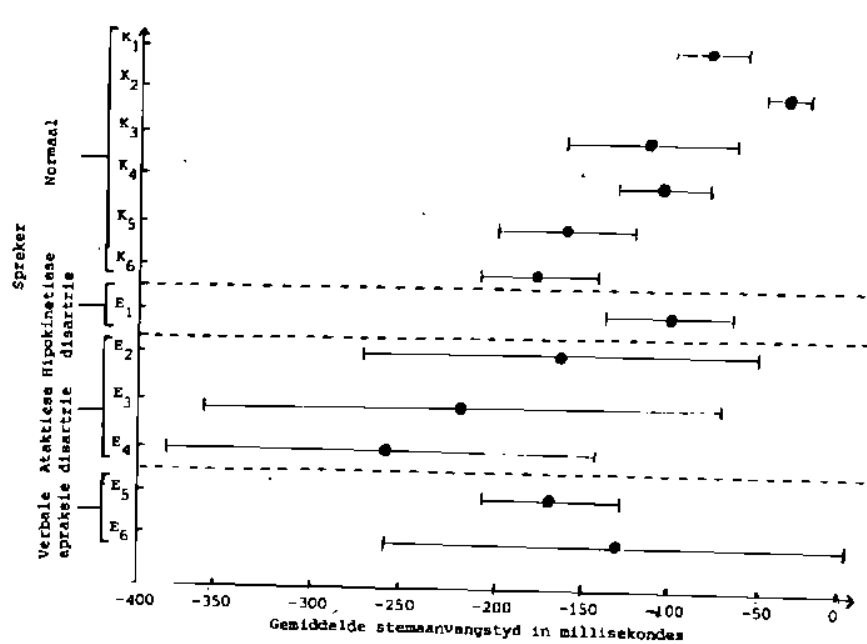

Figuur 3 Die gemiddelde SAT vir die klank /b/ met groot negatiewe waardes vir alle sprekers

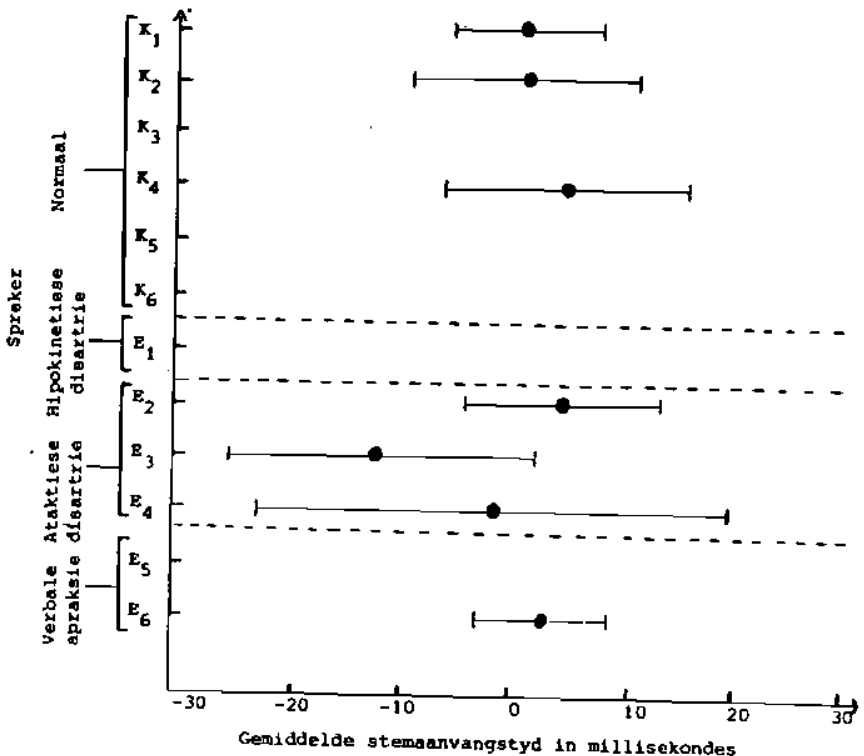

Figuur 4 Die gemiddelde SAT vir die klank /b/ met 'n waarde naby nul vir alle sprekers

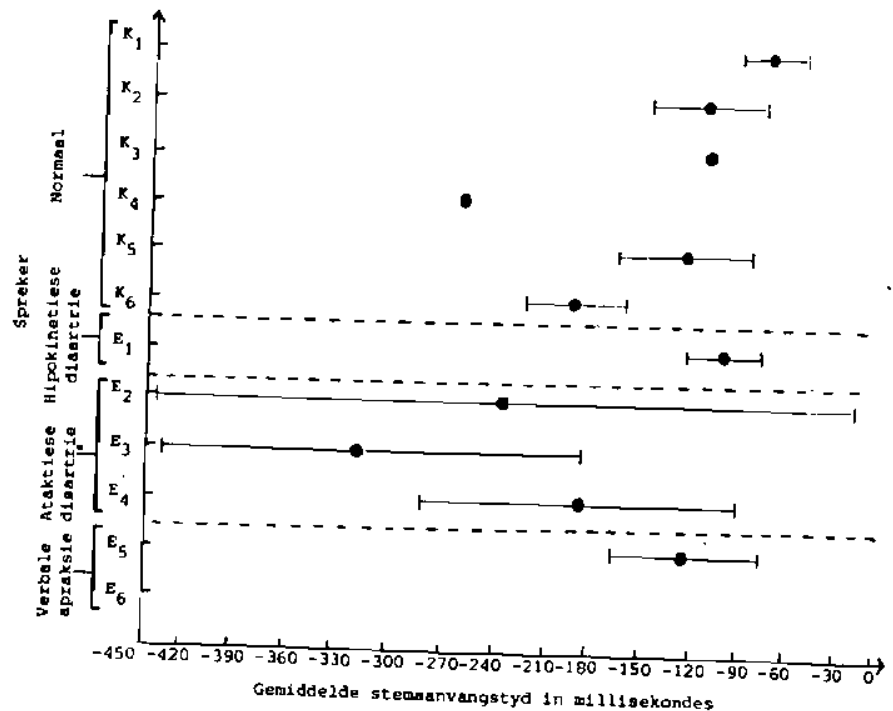

ᄃiguur 5 Die gemiddelde SAT vir die klank/d/ met groot legatiewe waardes vir alle sprekers

lie $/ \mathrm{b} /$ en $/ \mathrm{d} /$-klanke is daar 'n verdere verdeling gemaak. Die ede hiervoor is dat tydens die metings van $/ b / \mathrm{en} / \mathrm{d} / \mathrm{dit}$ opvalend was dat daar soms 'n groot negatiewe waarde gemeet is

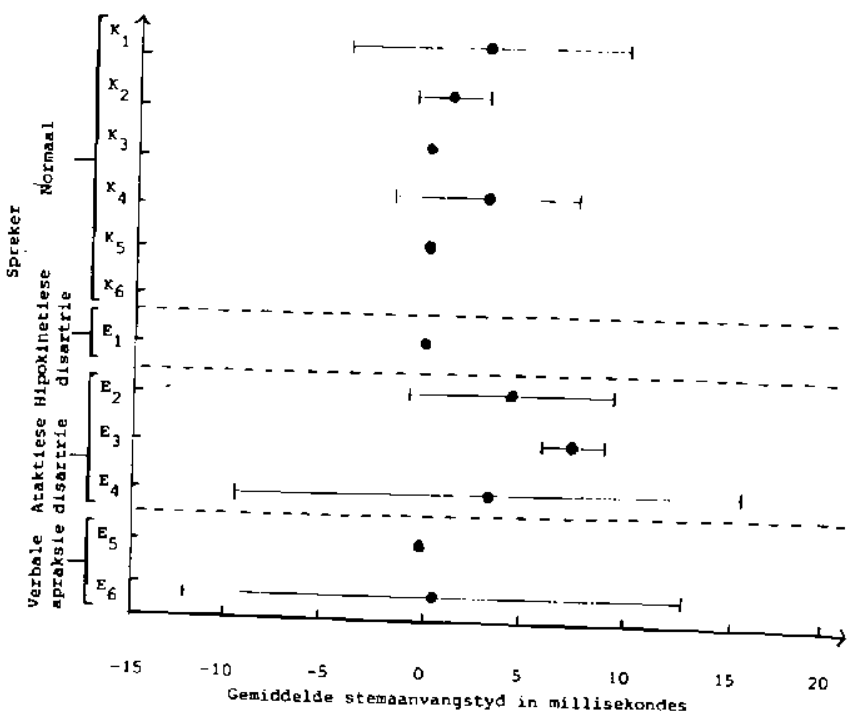

Figuur 6 Die gemiddelde SAT vir die klank /d/ met waardes naby nul vir alle sprekers

en soms 'n waarde wat naby nul lê. Die twee soorte waardes is gevolglik apart geneem en word apart in die grafieke weergegee.

Wat die gemiddelde SAT vir die klank /p/ vir alle sprekers (fig. 1) betref, blyk dit dat die kontrolegroep se variasie van die gemete tydsintervalle oor die algemeen kleiner is as dié by disartriese sprekers. Daar kon geen duidelike verskil in die gebiede waarin die stemaanvangstye vir die kontrolegroep of vir die eksperimentele groepe te lê gevind word $\mathrm{vir} / \mathrm{p} / \mathrm{nie}$, daar die gebiede waarin hul stemaanvangstye varieer, oorvleuel het.

In hierdie studie blyk die gemiddelde SAT vir/p/ in Afrikaans korter te wees as dié in Engels aangesien dit van ongeveer 15-50 m. sek. strek. Waardes vir Engelse stemlose eksplosiewe soos aangegee deur Lisker en A'bramson" is 60-100 m. sek, en dié deur Blumstein ${ }^{2}$ is $35-80 \mathrm{~m}$. sek. Aangesien die kontrolegroep se gemiddelde waardes baie varieer, kan daar nie norms opgestel word vir die SAT vir /p/ in Afrikaans nie, en kan geen uitspraak oor die lengte van die SAT in hierdie geval gemaak word nie. Wat die gemiddelde $S A T$ vir $/ t / v i r$ alle sprekers betref, geld baie van die oorwegings by $/ \mathrm{p} /$ ook vir $/ \mathrm{t} /$, soos bv, dat die gemiddelde SAT vir die normale sprekers weer eens baie varieer. Baie opvallend was die klein omvang wat by ataksiese $\left(E_{3}\right.$ en $\left.E_{4}\right)$ - en hipokinetiese $\left(E_{l}^{i}\right)$ disartriese sprekers voorgekom het in vergelyking met dié by $/ \mathrm{p} /$. Die apraktiese sprekers $\left(E_{5}\right.$ en $E_{6}$ ) se omvang van $S A T$ by $/ t /$ is ook kleiner as dié by /p/. Dit lyk dus of /t/ oor die algemeen makliker is om uit te spreek vir persone met 'n neuromotoriese disfunksie. Die gemiddelde stemaanvangstye vir/t/ verskil egter nie ooglopend van die gemiddelde stemaanvangstye vir $/ \mathrm{p} /$ nie. Uit die literatuur het dit geblyk dat die SAT toeneem soos wat die plek van artikulasie na agter in die mond beweeg. " Uit hierdie resultate kan so 'n afleiding egter nie gemaak word nie.

Wat die gemiddelde SAT vir $/ \mathrm{b} / \mathrm{met}$ 'n groot negatiewe waarde vir alle sprekers betref, is die gemiddelde SAT vir die stemhebbende klanke met 'n negatiewe waarde baie langer as die gemiddelde SAT vir stemlose klanke. Die rede hiervoor kan gevind word daarin dat stem vir 'n redelike lang tydperk die "plof" voorafgaan. 'n Baie groot variasie is weer eens by die 
ataktiese disartriese groep gevind. Hierdie groep het ook so 'n groot variasie by /p/, wat ook 'n bilabiale klank is, getoon. Dit is moontlik moeiliker om bilabiale klanke te produseer, aangesien die lippe twee organe is waarvan die beweging gesinchroniseerd moet plaasvind.

Wat die gemiddelde SAT vir die klank /b/ met 'n waarde naby nul betref, het die /b/-klanke van 'n paar sprekers, nl. $\mathrm{K}_{3}, \mathrm{~K}_{5}$, $K_{6}, E_{1}$ en $E_{5}$ geen waardes in hierdie gebied nie. Hierdie sprekers het moontlik die klanke meer bewustelik goed geartikuleer sodat 'n duidelike negatiewe waarde voorgekom het. Die sprekers vir wie daar wél grafieke opgeteken is, het hierdie /b/-klanke dus meer geproduseer soos wat dit in spontane spraak sou voorkom en wel met 'n waarde naby nul." "13 Die fonasie het gevolglik saam met die ploffing of baie kort daarna voorgekom. Dit word in die literatuur egter steeds as normaal beskou.

Wat die gemiddelde SAT vir die klank/d/ met 'n groot negatiewe waarde betref, geld dieselfde oorwegings wat vir die vorige klanke geld, ook hier, dit wil sê dat daar geen duidelike verskil in die gemiddelde SAT vir afgepaarde sprekers is nie. Die variasie by die ataktiese disartriese groepe is vir $/ d /$, met groot negatiewe waardes, groter as wat dit nog by enige ander klanke was. In teenstelling met die groot variasie by /d/ was daar weer baie min variasie by $/ \mathrm{t} /$.

Die gemiddelde SAT vir/d/met waardes naby nul: Hierdie resultate is soortgelyk aan die klein waardes vir $/ b /$, dit wil sê geen noemenswaardige verskil in die gemiddelde SAT kon raakgesien word nie.

Tydens die metings van stemaanvangstye is sekere kwalitatiewe waarnemings gemaak en 'n aantal foto's (fig. 7 en 8 ) is vanaf die ossilloskoopskerm geneem ten einde die resultate beter te illustreer. Figuur 7 is 'n voorbeeld van 'n negatiewe

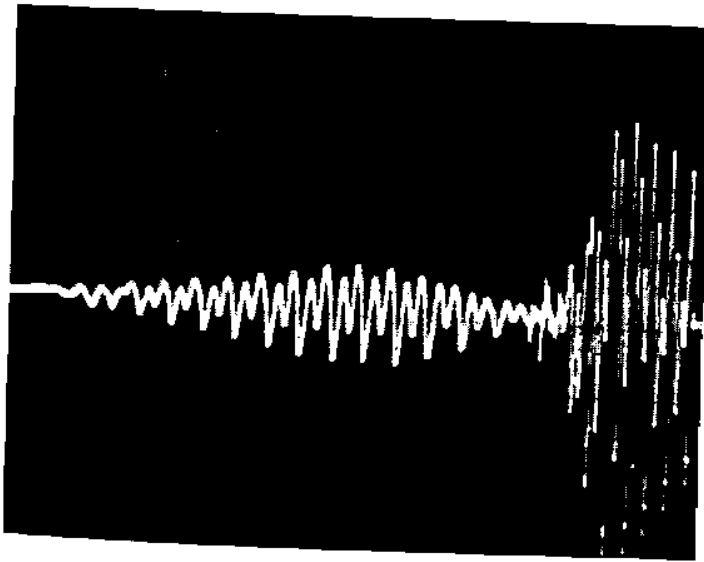

A

Figuur 7 Negatiewe SAT by /b/ soos uigespree male spreker

SAT by /b/ soos uitgespreek deur 'n normale spreker. Die meting is gedoen vanaf punt A tot by punt B. Hierdie is dus 'n voorbeeld waar laringale vibrasies die "plof' lank voorafgegaan het (stemvoorloop). Dit het by die eksperimentele sowel as die kontrolegroep voorgekom. Hierdie verskynsel kom soos wat meer voor in enkelwoorde en kort sinne en neem af 8 is ' $n$ tipiese sinne langer word in spontane spraak. 11,13 Figuur disfunksie wat voorbeeld van 'n persoon met 'n neuromotoriese Die Suid-Afrikaanse Tydskrif vir Kommunikasieafwykings, Vol. 30, 1983

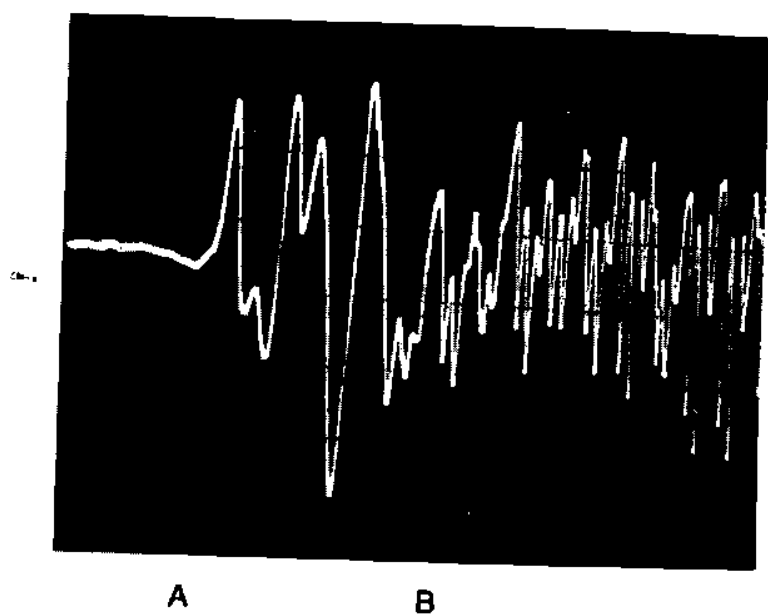

Figuur 8 Produksie van /b/ deur 'n neuromotories-gestremde persoon

seer. Die persoon probeer hier / bad/sê, maar die resultaat wat voortgebring is, was /pad/. Hierdie verskynsel van oorvleueling tussen stemhebbende en stemlose klanke deurdat die stemhebbende klank deur 'n stemlose klank vervang is, het dikwels by proefpersone met ataktiese disartrie en verbale apraksie voorgekom. Dit het by ongeveer $50 \%$ van die stemhebbende uitings van bogenoemde sprekers voorgekom.

\section{BESPREKING VAN RESULTATE}

Die verskynsel dat die gemiddelde SAT by die normale sprekers baie gevarieer het in die opsig dat die omvang van die SAT-waardes nie konstant was nie, het resultate baie gekompliseer. Daar was wel oorvleueling van waardes by die verskillende indiwidue, maar nie by die groep as 'n geheel nie. Hierdie bevinding is teenstrydig met dié soos verkry deur Zlatin ${ }^{13}$ waar hy gevind het dat die omvang van SAT by normale sprekers wel konstant is. Jansen ${ }^{8}$ het egter uit praktiese ondervinding gerapporteer dat die SAT by normale sprekers baje wissel van indiwidu tot indiwidu. As gevolg van die bogenoemde feit was dit nie moontlik om norms vir normale SAT in Afrikaans te bepaal ten einde fyner waarnemings te maak nie.

Die volgende verskille is gevind tussen klanke ten opsigte van SAT: Dit blyk dat middelalveolêr bladlinguale klanke vir die ataktiese disartriese sprekers makliker is om te produseer as bilabiale klanke, aangesien die variasie by $/ t /$ relatief kleiner was as dié by $/ \mathrm{p} / \mathrm{en} / \mathrm{b} /$. Bilabiale klanke is moontlik moeiliker omdat twee organe, nl. die lippe gesinchroniseerd moet beweeg in teenstelling met 'n enkele orgaan, $\mathrm{nl}$. die tong wat by middelalveolêr bladlinguale klanke moet beweeg. Beter koördinasie word dus in die eerste geval vereis. Aangesien algemene ongekoördineerdheid ' $n$ eienskap van ataksiese disartrie is, verklaar dit moontlik die verskynsel dat bilabiale klanke moeiliker is om te produseer as middelalveolêr bladlinguale klanke, daar dit meer koördinasie verg.9, 12

Die ataksiese disartriese sprekers het baie meer variasies in SAT getoon as die ander sprekers. Dit is dus vir hierdie groep moeilik om hul SAT te beheer. Dit kan die gevolg wees van die algemene wankoördinasie, onwillekeurige bewegings en hipotonus wat in ataktiese disartrie voorkom. Die hipotonus gee aanleiding tot parese van die spiere met gevolglike vinnige uitputting. ${ }^{5,}{ }^{12}$ Hierdie uitputting van die spiere met gevolglike stadige spraak kon moontlik bygedra het tot die variasie in die SAT. 
'n Ongeveer 50\%-oorvleueling van stemhebbende en stemlose klanke is by twee $\left(E_{2}\right.$ en $\left.E_{3}\right)$ uit die drie persone in die groep met verworwe serebellêre letsels (ataktiese disartrie) opgemerk. Stemhebbende klanke is met stemlose klanke wat ooreenstem ten opsigte van plek van artikulasie, vervang. Grunwell en Huskins ${ }^{5}$ rapporteer dieselfde bevinding in hul studie. Hierdie stemhebbende/stemlose vervangings kan moontlik toegeskryf word aan 'n verlies aan sinergisme van die spierbewegings. Die SAT is moontlik afhanklik van die sinchronisering van die beweging van die glottis, die lippe en die tong. Die verskynsel dat die derde persoon $\left(E_{4}\right)$ in die bogenoemde groep nie oorvleueling van stemhebbende/stemlose klanke vertoon het nie, kan moontik verklaar word aan die hand van die resultate soos verkry deur Kent, Netsell en Abbs. ${ }^{10}$ Hierdie skrywers het 'n afwyking in die SAT, ooreenstemmend met die graad van aantasting, by ataktiese disartrie gevind. Die afleiding wat gemaak word, nl. dat hierdie persoon se graad van disartrie ligter is as dié van die ander, word gesteun deur die feit dat die betrokke persoon liggaamlik minder aangetas is as die ander twee persone.

Die proefpersoon met basale gangliaskade het min variasie in die omvang van SAT-waardes getoon en in teenstelling met die ataktiese disartriese sprekers, het geen vervangings van fonetiese kategorieë, bv. $/ \mathrm{b} /-/ \mathrm{p} /$ voorgekom nie. Dié persoon se stemaanvangstydwaardes blyk ook nie afwykend van die normale, soos in hierdie studie verkry, te wees nie. Dit kan waarskynlik die gevolg wees van die medikasie wat die persoon tans gebruik. Die medikasie verminder die onwillekeurige bewegings wat kenmerkend van Parkinsonisme is, en sal gevolglik die mate van dissinchronisering tussen verskillende organe ook verminder.

Dieselfde oorvleueling van stemhebbende en stemlose klanke soos by die groep met ataktiese disartrie gevind is, is by een van die twee persone met verbale apraksie $\left(\mathrm{E}_{6}\right)$ aangetref. Vyftig persent van die stemhebbende klanke is ouditief as stemlose klanke waargeneem. Hierdie oudiţiewe waarneming is bevestig deur die ossillasies op die ossilloskoopskerm wat tipies verteenwoordigend van stemlose klanke was. Dit stem presies ooreen met die resultate soos verkry deur Freeman, Sands en Harris. ${ }^{4}$ Dissinchronisering van die velum en die tong kom by apraktiese sprekers tydens artikulasie voor. ${ }^{7} \mathrm{Dit}$ is moontlik dat daar ook dissinchronisering by die beweging van artikulators, nl. die tong en die lippe onderskeidelik en die glottis kan voorkom wat 'n gevolglike invloed op die SAT sal hê. Hierdie resultaat stem ook ooreen met dié soos verkry deur Blumstein, Cooper, Zurif en Caramazza.' Hulle het gevind dat pasiënte met anterior serebrale letsels hoofsaaklik 'n gebrek aan sinergisme en dus fonetiese vervangings vertoon. Die fonetiese vervangings was in verskeie gevalle foutiewe allofone van bv. / $t$ / wat dan eerder as behorende tot / $/$ / waargeneem is. Die huidige studie was nie intensief genoeg om so 'n waarneming te maak nie, maar die moontlikheid bestaan dat dit hier ook die geval kon wees. Die dissinchronisering hier ter sprake lyk na 'n probleem met betrekking tot die beheer van willekeurige spierbewegings. Hierdie fonetiese afbraak is weer eens ' $n$ bewys dat artikulatoriese apraksie 'n motoriese uitval is.

Freeman, Sands en Harris ${ }^{4}$ het gevind dat apraktiese sprekers nooit 'n stemvoorloop, met ander woorde teenwoordigheid van stem voor die fyn ossillasies wat die stemhebbende eksplosief verteenwoordig, gebruik het nie. Die vraag of die genoemde probleem idiosinkraties van aard is, het by die bogenoemde skrywers ontstaan. Uit die huidige studie blyk dit dat dit moontlik 'n idiosinkratiese probleem is, aangesien die proefpersone met verbale apraksie, wel stemvoorloop getoon het. Dit moet egter gemeld word dat stemvoorloop by $\mathrm{E}_{6}$ nie konstant voorgekom het nie, maar slegs af en toe. Die ander klanke deur hierdie persoon geproduseer wat deur middel van luistertoetse as stemhebbend geklassifiseer is, het waardes naby aan nul gehad. Hierdie waardes neig dus meer na positiewe stemaanvangstydwaardes waar klanke as stemloos waargeneem word. Dit is moontlik ' $n$ aanloop tot die fonetiese vervangings wat waarskynlik 'n afwyking in ooreenstemming met die graad van aantasting van die spreker is. Indien bogenoemde wél so is, is dit moontlik dat die proefpersone wat Freeman, Sands en Harris ${ }^{4}$ gebruik het in hul studie 'n erger graad van aantasting vertoon het as die persone wat vir hierdie studie gebruik is. Daar kan egter slegs oor hierdie aspek gespekuleer word.

Tydens die meting van die SAT van die proefpersone met verbale apraksie, is 'n onstabiliteit in die stem opgemerk wat nie by die normale of disartriese sprekers voorgekom het nie. Hierdie onstabiliteit het die volgende behels, nl. dat 'n paar pulserings van stem voorgekom het waarna die stem heeltemal opgehou het om dan weer later in die produksie te begin. Dit stem ooreen met resultate soos verkry deur Freeman, Sands en Harris. ${ }^{4}$ Die verskynsel kan moontlik toegeskryf word aan die soekbewegings na die plek van artikulasie wat die spreker vertoon, nadat hy reeds begin het om stem te inisieer. Die stem stop dan vir die tydsduur van die soekbewegings om weer te begin, nadat die spreker die plek en omvang van artikulasie gevind het.

Beide die apraktiese sprekers se spraakspoed was stadiger as normaal met gevolglike verlies aan prosodie. Dit is heel waarskynlik as gevolg van hul prgings om foute te vermy, aangesien hulle ten volle daarvan bewus is wanneer hulle 'n foutiewe produksie lewer. Daar kon egter geen betekenisvolle effek van die stadige spraakspoed op die gemiddelde SAT van hierdie sprekers gesien word nie.

\section{GEVOLGTREKKINGS}

Opsommend kan dus gesê word dat die SAT by die apraktiese en ataktiese disartriese sprekers wél afwykend is soos gesien teenoor die normale. Dit is egter nie omdat daar 'n verskil in die gemiddelde waardes van SAT is nie, maar in die grootte van die omvang van die stemaanvangstydwaardes.

Die meeste wisselvalligheid is by die groep met ataktiese disartrie opgemerk, aangesien hierdie sprekers baie groter variasies in die gemete tydsintervalle toon in yergelyking met die ander groepe.

Die hipokinetiese disartriese spreker se omvang van die stemaanvangstydwaardes is nie beduidend́ groter as dié van die normale sprekers nie

By sowel die groep met verworwe serebellêre letsels as die groep met verbale apraksie is fonetiese vervangings ten opsigte van stemhebbendheid en stemloosheid gevind, nl. dat die stemhebbende klanke met stemlose klanke vervang word. 
Die gemiddelde stemaanvangstye vir sowel die twee eksperimentele groepe as die kontrolegroep stem in so 'n mate ooreen dat daar nie vir elke groep 'n afsonderlike kenmerkende SAT bepaal kon word nie.

Etlike verskille in die fonetiese parameter SAT is dus tussen apraktiese en disartriese sprekers opgemerk. Die verskille was egter baie klein en nie konstant beduidend nie.

\section{VERWYSINGS}

1. Blumstein, S. E., Cooper, W. E., Zurif, E. B. en Caramazza, A. (1977): The Perception and Production of Voice-onset Time in Aphasia. Neuropsychologia, 15, 371-383.

2. Blumstein, S. E., Cooper, W. E., Goodglass, H., Statlender, S. en Gottlieb, J. (1980): Production Deficits in Aphasia: A Voice-onset Time Analysis. Brain and Language, 9, 153-170.

3. Darley, F. L., Aronson, A. E. en Brown, J. R. (1969): Differential Diagnostic Pattern of Dysarthria. Journal of Speech and Hearing Research, 12, 246-269.

4. Freeman, F. J., Sands, E. S. en Harris, K. S. (1978): Temporal Co-ordination of Phonation and Articulation in a Case of Verbal Apraxia: A Voice-onset Time Study. Brain and Language, 6, 106-111.

5. Grunwell, P. en Huskins, S. (1979): Intelligibility in Acquired Dysarthria - A Neuro-phonetic Approach: Three
Case Studies. Journal of Communication Disorders, 12 ,
9-22.

6. Itoh, M. Sasanuma, S. en Ushijima, T. (1979): Velar Movements during Speech in a Patient with Apraxia of Speech. Brain and Language, 7, 227-239.

7. Itoh, M., Sasanuma, S., Hirose, H., Yoshioka, H. en Ushijima, T. (1980): Abnormal Articulatory Dynamics in a Patient with Apraxia of Speech: X-ray Microbeam Observation. Brain and Language, 11, 66-75.

8. Jansen, L. P. C. (1982): For. Wet. Laboratorium, Pretoria. Persoonlike mededeling.

9. Kent, R. en Netsell, R. (1975): A Case Study of an Ataxic Dysarthric: Cineradiographic and Spectrographic Observations. Joumal of Speech and Hearing Research, 40, 115-134.

10. Kent, R. D., Netsell, R. en Abbs, J. H. (1979): Acoustic Characteristics of Dysarthria associated with Cerebellar Disease. Journal of Speech and Hearing Research, 22, 627-648.

11. Lisker, L. en Abramson, A. S. (1967): Some effects of Context on Voice-onset Time in English Stops. Language and Speech, 10, 1-28.

12. Netsell, R. en Kent, R. D. (1976): Paroxysmal Ataxic Dysarthria. Journal of Speech and Hearing Disorders, 41, 93-109.

13. Zlatin, M. A. (1974): Voicing Contrast: Perceptual and Productive Voice-onset Time, Characteristics of Adults. The Journal of the Acoustical Society of America, 56, 